\title{
Heavy metal contamination from treated sewage effluents
}

\author{
S. K. Al-Musharafi ${ }^{1}$, I. Y. Mahmoud ${ }^{2}$ \& S. N. Al-Bahry ${ }^{3}$ \\ ${ }^{1}$ Sur College of Applied Sciences, Oman \\ ${ }^{2}$ Department of Biological Sciences and Chemistry, \\ University of Nizwa, Oman \\ ${ }^{3}$ Department of Biology, College of Science, \\ Sultan Qaboos University, Oman
}

\begin{abstract}
Excessive exposure of heavy metals is known to have deleterious effects on health and has been shown to cause various diseases. The determination of heavy metals in sewage is important for monitoring environmental pollution caused by treated sewage effluents (TSE). Rare rainfall in Oman and lack of fresh water has led the authorities to recycle sewage effluents. However, the environmental impact related to heavy metals in sewage effluents is a serious health issue. Three sewage treatment plants (STPs) were used in this study. Water and sewage samples were analyzed for heavy metals; $\mathrm{Al}, \mathrm{As}, \mathrm{B}, \mathrm{Cd}, \mathrm{Co}, \mathrm{Cr}, \mathrm{Cu}, \mathrm{Fe}, \mathrm{Hg}, \mathrm{Mn}$, $\mathrm{Mo}, \mathrm{NI}, \mathrm{Pb}, \mathrm{V}$ and $\mathrm{Zn}$ using Inductively Coupled Plasma Optical Emission Spectrometer (ICP-OES) type Perkin Elmer 3300 DV ICP. Heavy metal concentration in the three STPs varied significantly and it was in correlation with heavy metals in sludge and soil irrigated with TSE. STPs used in industrial areas had higher concentration of heavy metals compared to STPs from residential communities, hospitals, and public institutions. In general, the highest concentration among the heavy metals from sludge was $\mathrm{Pb}, \mathrm{Hg}, \mathrm{Cu}, \mathrm{Cr}, \mathrm{Ni}, \mathrm{Zn}$ and $\mathrm{Cd}$. The results of this investigation indicates that there is a potential threat reusing recycled water and sludge which can infiltrate livestock, wildlife which impose the risk of spreading human diseases.
\end{abstract} Keywords: heavy metals, treated sewage effluent, sludge, contamination. 


\section{Introduction}

Heavy metal pollution is likely to produce widespread effects on terrestrial and marine wild life. Generally, heavy metals toxic to living organisms in the form of cations due to their ability to bind to biomolecules such as proteins [1]. In Oman during the last ten years, it was observed that there was a steady heavy metals accumulation in wild life specifically accumulation of $\mathrm{Co}, \mathrm{Hg}, \mathrm{Pb}$ and $\mathrm{Sn}$ [2]. It was reported that $\mathrm{Co}$ is an essential element for vitamin $\mathrm{B}_{12}$ but can be toxic when it is in an inorganic form. It was found to be a carcinogenic element [3]. The main source of Co may be derived from anthropogenic input via run-off from ceramic industries which is commonly located on the coastal regions of Oman and may also contaminate the marine wild life. In addition, $\mathrm{Hg}$ is a very toxic element and it is a non-essential element to organisms. This element was found to accumulate in fish with up to a 10,000-fold bio-concentration factor [2]. The majority of mercury concentration in tissues occurs as methyl mercury. Biomagnification of mercury through food chain occurs with age as a result of slow elimination in tissue $[4,5]$. Mercury can be released to the environment through industrial and agricultural applications [5]. The major contributor of mercury pollution is from coal-burning power plants. Sn is essential element in many organisms but at blood concentrations can be highly dangerous to organisms [4]. Like mercury, lead is a non-essential element and its toxicity increases as a result of accumulation in tissues causing disabilities [2]. Led was also found in plant tissue in Oman. Plants exposed to high led concentrations expressed stress proteins and deformed roots [6].

Recent studies indicated that heavy metal pollution played a major role in the poisoning and decline of various populations [7-12]. Continuous contamination of living organisms to heavy metals overtime can lead to gradual accumulation in various tissues and ultimately fatal [13].

The current studies related to the effects of transformation, detoxification and excretion of heavy metals is insufficient. Further investigation on the effects of heavy metals is urgently needed for wild life and public health protection. Heavy metals $\mathrm{Co}, \mathrm{Cu}, \mathrm{Mn}$, and $\mathrm{Zn}$ are essential elements important for the enzymatic activities but still can be toxic at high concentrations. On the other hand, nonessential metals are not involved in any metabolic process but its accumulation in tissues is an indication of environmental pollution of heavy metals [11]. Heavy metals are known to cause serious diseases especially when they are found excessively in animals and plants $[3,14,15]$ found 15 heavy metals in marine fish and bivalves in the Gulf of Oman and Arabian Gulf. Al-Rawahi et al. [2] reported the presence of 12 different heavy metals in eggs and hatchlings of green turtles in Oman which is resulted from contaminated effluent. 
Food safety is of an international concern. Vegetables subjected to heavy metal contamination when irrigated by wastewater. Mapanda et al. [16] reported accumulation of heavy metals in vegetables irrigated by contaminated recycled water. Solid waste and wastewater was also reported in underground water beds and was a cause of health concern [17]. We found heavy metals from treated and untreated sewage effluents penetrated well-water. Some of the wells exceeded the allowed minimum permissible levels in Oman (data not shown).

It is essential to indicate that sewage effluents may play a major role in spreading and consequently contaminating environment and wild life. Its accumulation in food chain can be detrimental to human health. Consumption of food and drinking water contaminated with high concentration of heavy metals cause a variety of chronic diseases such as chronic anaemia, liver cirrhosis, renal failure and cancers $[18,19]$.

The aim of this study is to investigate the role of sewage in spreading and contaminating environment and wild life by heavy metals.

\section{Materials and methods}

\subsection{Sample collection}

Three sewage treatment plants (STPs) were selected in this study in Muscat, Oman. TSE generated form these plants are available for public usage including irrigation of public greeneries. The selected STPs were as follows: A = Industrial STP only, B = Industrial and residential STP, C = Hospital STP. Samples were collected weekly over a period of two months. Samples were collected and analysed following the standard methods [20]. 1L sterile, labelled glass bottles were used to collect the effluent samples for heavy metal analysis [21]. Samples were preserved in a cooler at $10^{\circ} \mathrm{C}[20]$.

Soil and sludge samples were dried at $105^{\circ} \mathrm{C}$ for $3 \mathrm{~h}$. Dried samples $(0.2 \mathrm{~g})$ were weighed in perfluoroalkoxy polymer container and treated with $4 \mathrm{ml}$ of concentrated nitric acid and $0.5 \mathrm{ml}$ of hydrofluoric acid. The samples treated in a microwave for $40 \mathrm{~min}$. Then the samples were diluted to $100 \mathrm{ml}$ with water. Sample solutions were diluted with water to give a final concentration of $1 \mathrm{~g} / \mathrm{l}$ [22]. TSE samples were filtered and analysed for $\mathrm{Al}, \mathrm{As}, \mathrm{B}, \mathrm{Ba}, \mathrm{Cd}, \mathrm{Cr}, \mathrm{Cu}, \mathrm{Fe}$, $\mathrm{Hg}, \mathrm{Mn}, \mathrm{Ni}, \mathrm{Pb}, \mathrm{Sb}, \mathrm{Sc}, \mathrm{Se}$ and $\mathrm{Zn}$ using inductively coupled plasma optical emission spectrometer (ICP-OES) type Perkin Elmer 3300 DV ICP (USA). Blank and certified reference materials were used as controls. Heavy metal concentrations were compared to the Omani Standard of Wastewater Reuse, [23] (Table1). Unrestricted irrigation TSE is used for irrigation of vegetable and salad, crops eaten uncooked, sports fields and public parks. Restricted irrigation TSE is used for Cereal crops, industrial crops, fodder crops, pasture and trees. Minimum Permissible Levels (MPL) for SB and Sc are unavailable [24]. 
Table 1: Heavy metal standards of wastewater reuse in Oman.

\begin{tabular}{|c|c|c|c|}
\hline \multirow[b]{2}{*}{ Metal } & \multirow[b]{2}{*}{ Symbol } & \multicolumn{2}{|c|}{ Minimum Permissible Levels (MPL) } \\
\hline & & $\begin{array}{c}\text { Unrestricted irrigation } \\
(\mathrm{ppb})\end{array}$ & $\begin{array}{c}\text { Restricted irrigation } \\
\text { (ppb) }\end{array}$ \\
\hline Aluminum & $\mathrm{Al}$ & 5 & 5 \\
\hline Arsenic & As & 0.1 & 0.1 \\
\hline Barium & $\mathrm{Ba}$ & 1 & 2 \\
\hline Boron & $\mathrm{B}$ & 0.5 & 1 \\
\hline Cadmium & $\mathrm{Cd}$ & 0.01 & 0.01 \\
\hline Chromium & $\mathrm{Cr}$ & 0.05 & 0.05 \\
\hline Copper & $\mathrm{Cu}$ & 0.05 & 1 \\
\hline Iron & $\mathrm{Fe}$ & 1 & 5 \\
\hline Mercury & $\mathrm{Hg}$ & 0.001 & 0.001 \\
\hline Manganese & $\mathrm{Mn}$ & 0.1 & 0.5 \\
\hline Nickel & $\mathrm{Ni}$ & 0.1 & 0.1 \\
\hline Lead & $\mathrm{Pb}$ & 0.1 & 0.2 \\
\hline Antimony & $\mathrm{Sb}$ & - & - \\
\hline Scandium & $\mathrm{Sc}$ & - & - \\
\hline Selenium & $\mathrm{Se}$ & 0.02 & 0.02 \\
\hline Zinc & $\mathrm{Zn}$ & 5 & 5 \\
\hline
\end{tabular}

\section{Results}

Sludge samples at three localities in Muscat, Oman were analyzed in 2010. Heavy metals $\mathrm{Pb}, \mathrm{Hg}, \mathrm{Cu}, \mathrm{Ni}, \mathrm{Zn}, \mathrm{Cr}$ and $\mathrm{Cd}$ were generally found at high concentrations. At medium concentrations were $\mathrm{Sb}, \mathrm{Al}$, As, B and $\mathrm{Ba}$; at lower concentrations were Fe, Mn and Se (Figure 1).

Heavy metal concentration in TSE from the three localities demonstrated a wide variation in values without any specific patterns. The highest heavy metal concentrations were $\mathrm{Pb}, \mathrm{Zn}, \mathrm{Cd}$, but only in localities $\mathrm{A}$ and $\mathrm{B}$ while $\mathrm{C}$ was significantly low. Locality $\mathrm{C}$ is where the hospital was located. $\mathrm{B}, \mathrm{Cr}, \mathrm{Cu}, \mathrm{Fe}, \mathrm{Hg}$ and $\mathrm{Sb}$ were next in concentrations and again in localities $\mathrm{A}$ and $\mathrm{B}$ were generally with dominant values. The third group $\mathrm{Al}, \mathrm{As}, \mathrm{Ba}, \mathrm{Ni}, \mathrm{Sc}$ and $\mathrm{Se}$ were at low levels in the three localities (Figure 2).

The soil heavy metal contamination was from the samples were taken from each locality demonstrated a close pattern to the STP values in the three localities. Many of the levels of the heavy metal surveyed from the sludge in the three localities, STP sludge and soil surpassed Omani standards safety levels (Figures 1-3). 


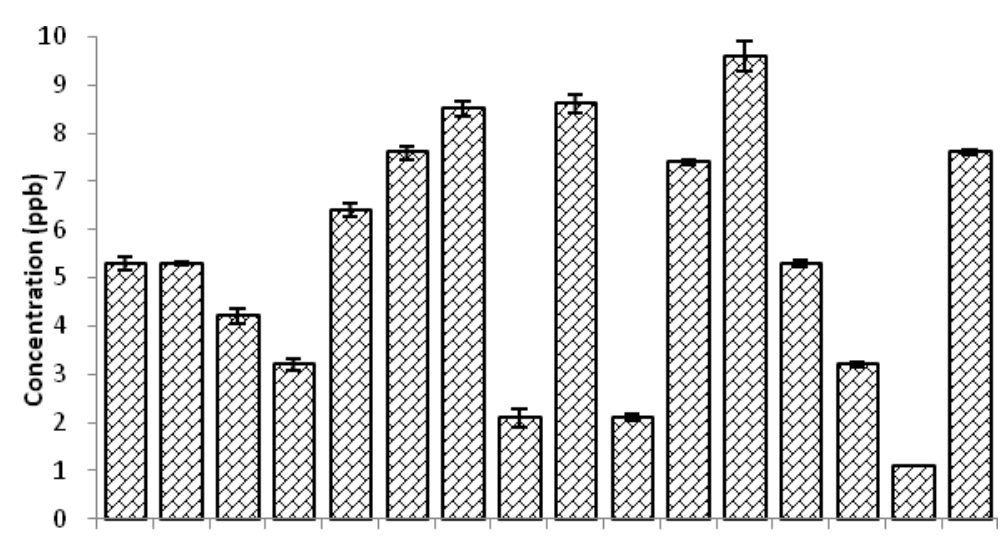

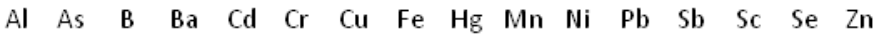

Heavy metal

Figure 1: Heavy metals from sludge.

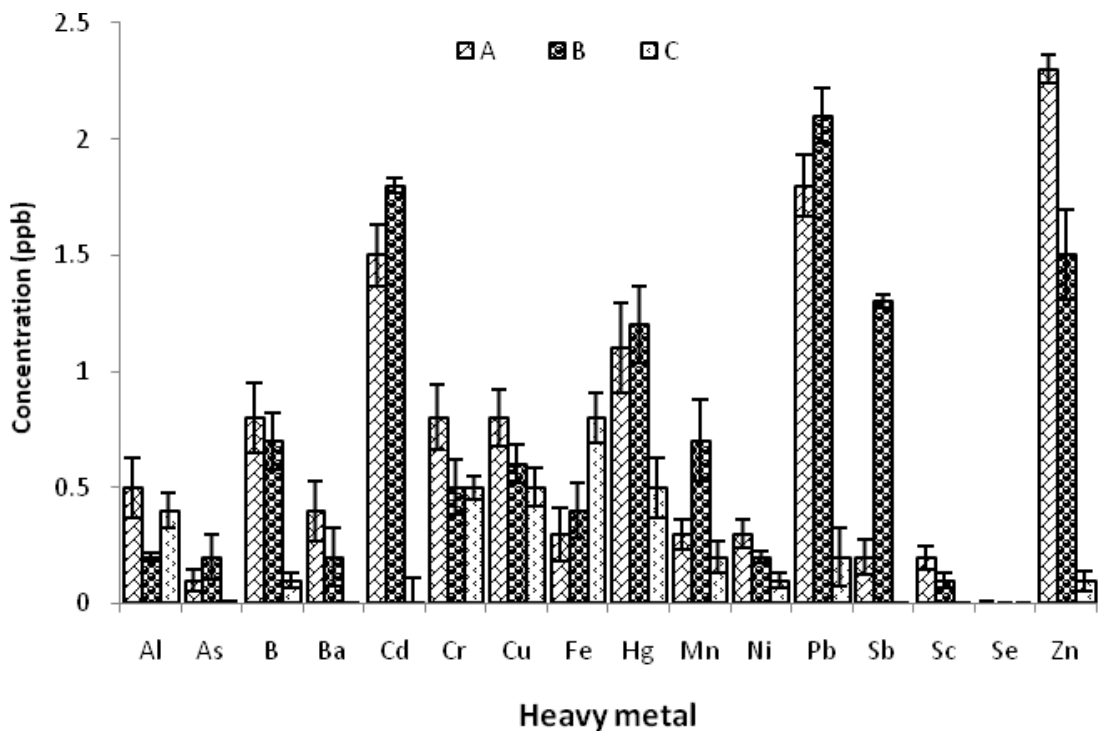

Figure 2: $\quad$ Samples of heavy metal concentrations ( $\mathrm{ppb}$ ) taken from STP at three different localities in Muscat, Oman. $\mathrm{Zn}, \mathrm{Pb}$ and $\mathrm{Cd}$ were found at high concentrations in localities A and B. 


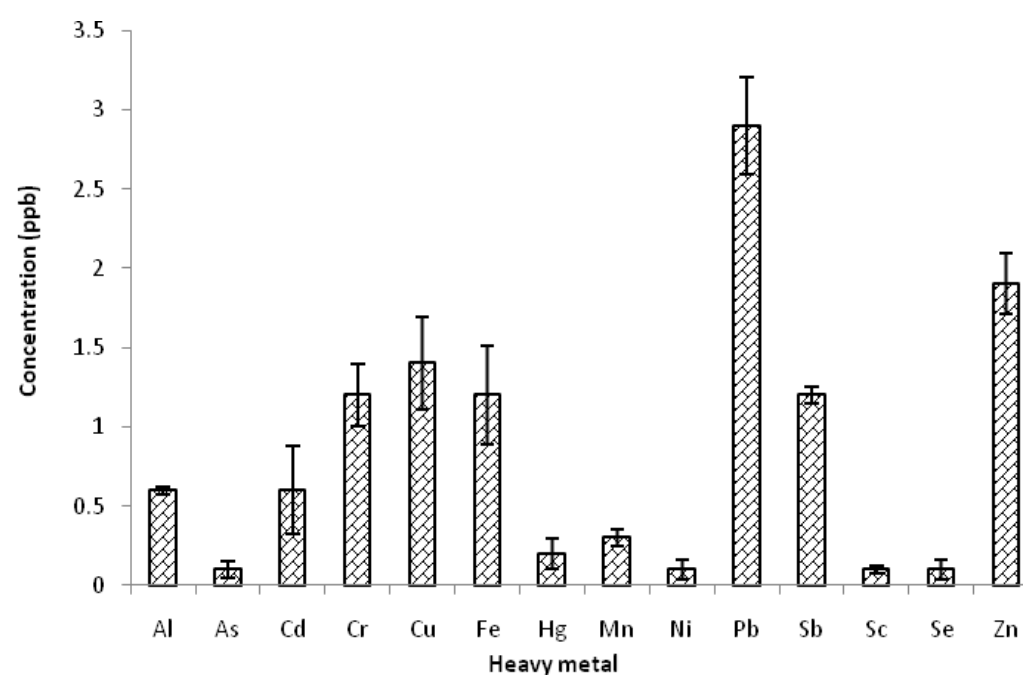

Figure 3: Heavy metals in soil samples irrigated by TSE from STP localities in Muscat, Oman.

\section{Discussion}

Due to low annual rainfall and arid conditions in Oman, reuse of TSE has become a necessity. However, several environmental and public health problems are now facing the country. Specifically, the reuse of TSE and sludge which resulted in accumulation of toxic compounds in soil and rapid infiltration into underground water affecting public health, animals and plants.

In this study, the detection of heavy metals in sludge and treated sewage effluents were evidently found to contribute to pollution of soil affecting the environment. As a result, heavy metals infiltration into the soil occurring very rapidly and consequently contaminates water and the whole food chain. Heavy metals in drinking water and food were found to be responsible for a several chronic diseases such as chronic anemia, liver cirrhosis, renal failure and cancers $[18,19]$.

In this study, throughout the three localities, several heavy metals exceeded the MPL levels set by the Omani authorities [23, 24]. Several international organizations recommended safe levels of heavy metals in food and drinking water [25-29]. However, many of the heavy metals in this study exceeded the safety levels which made food and drinking water not suitable for consumption. Heavy metal values from localities A and B surpassed MPL. The STPs from these localities are fed by water from industrial sources. It was reported that most of heavy metals contamination are related to industries [30, 31]. It is well documented that heavy metals in underground water is also contributed by a lithology of rocks and quantity of infiltrating rainfall. However, water composition also affected by human activities [32]. Heavy metal impurities penetrate the soil to reach underground water through sewage and industrial 
effluents were also reported [33]. Such water, if used for drinking and irrigation of farms may be detrimental to health. The use of sludge in soil has to pass standard safety conditions before reused. Sludge must be kept at a minimum of 3 weeks before grazing or harvesting crops. The use of sludge is prohibited in soils when fruits or vegetables are growing [24]. The results of this investigation show that there is an alarming condition facing human health, ecology and environment in Oman. There is a steady increase in the levels of heavy metals throughout the three study areas. Unless there is a stringent enforcement, the danger of heavy metals infiltration might be harmful in the future affecting wild life and human health.

\section{Conclusions}

Soil contained heavy metals probably resulted from contaminated TSE and sludge. The highest concentrations of the heavy metals in all samples were $\mathrm{Pb}$ and $\mathrm{Zn}$. The data indicate that the major source of the heavy metal concentrations originated from STP used for industrial effluents and the lowest was from the hospital. Several heavy metals have surpassed the MPL levels.

\section{References}

[1] Shahidul, I. and Tanaka, M., Impacts of pollution on coastal and marine ecosystems including coastal and marine fisheries and approach for management: a review and synthesis. Marine Pollution Bulletin, 48, pp. 624-649, 2004.

[2] Al-Rawahy, S.H., Al Kindi, A.Y., Elshafie, A., Mahmoud, I.Y., Al-Bahry, S.N., Al-Siyabi, S.S., Mansour, M.H. and Al-Kiyumi, A.A., Accumulation of metals in the egg yolk and liver of hatchling of green turtles Chelonia mydas at Ras Al Hadd, Sultanate of Oman. ANSI: Journal of Biological Sciences, 7, pp. 925-930, 2007.

[3] Ayres, D.C., Hellier, D.G., Dictionary of Environmentally Important Chemicals. Blackie Academic and Professional: London, 1998.

[4] Harrison, R.M., (ed). Pollution: Causes, Effects and Control. Royal Society of Chemistry, Cambridge, 2001.

[5] Nigro, M., Leonzio, C., Intracellular storage of mercury and selenium in different marine vertebrates. Marine Ecology Progress Series, 135, pp. 137 $143,1996$.

[6] Jaffer, T.M.R., Eltayeb, E.A., Farooq S.A. and Al-Bahry, S.N. Lead pollution levels in Sultanate of Oman and its effect on plant growth and development. Pakistan Journal of Biological Sciences, 2, pp. 25-30, 1999.

[7] Zauke, G.P., Clason, B., Savinov, V.M. and Savinova, T., Heavy metals of inshore Benthic invertebrates from the Barents Sea. The Science of the Total Environment, 306, pp. 99-110, 2003.

[8] Jeffree, R.A., Warnau, M., Oberhansli, F., Teyssie, J., Bioaccumulation of heavy metals and radionuclides from seawater by encased embryos of the 
spotted dogfish Scyliorhinus canicula. Marine Pollution Bulletin, 52, pp. 1278-1286, 2006.

[9] Kannan, K., Agusa, T., Perrotta, E., Thomas, N.J. and Tanabe, S., Comparison of trace element concentrations in livers of diseased, emaciated and non-diseased southern sea otters from the California coast. Chemosphere, 65, pp. 2160-2167, 2006.

[10] Harper, E.R., St Leger, J.A., Westberg, J.A., Mazzaro, L., Schmitt, T., Reidarson, T.H., Tucker, M., Cross, D.H. and Puschner, B., Tissue heavy metal concentrations of stranded California sea lions (Zalophus californianus) in Southern California. Environmental Pollution, 147, pp. 677-682, 2007.

[11] Kojadinovic, J., Potier, M., Le, Corre, M., Cosson, R.P. and Bustamante, P., Bioaccumulation of trace elements in pelagic fish from the Western Indian Ocean. Environmental Pollution, 146, 548-566, 2007.

[12] Storelli, M.M., Barone, G., Storelli, A., Marcotrigiano, G.O., Total and subcellular distribution of trace elements $(\mathrm{Cd}, \mathrm{Cu}$ and $\mathrm{Zn})$ in the liver and kidney of green turtles (Chelonia mydas) from the Mediterranean Sea. Chemosphere, 70, pp. 908-913, 2008.

[13] Fent, K., Ecotoxicology of organotin compounds. Critical Reviews in Toxicology, 26, pp. 1-117, 1996.

[14] Talavera-Saenz, A., Gardner, S.C., Rodriquez, R.R. and Vargas, B.A., Metal profiles used as environmental markers of green turtle (Chelonia mydas) foraging resources. Science of the Total Environment, 373, pp. 94102, 2007.

[15] De Mora, S., Fowler, S.W., Wyse, E. and Azemard, S., Distribution of heavy metals in marine bivalves, fish and coastal sediments in the Gulf and Gulf of Oman. Marine Pollution Bulletin, 49, pp. 410-424, 2004.

[16] Mapanda, F., Mangwayana, E.N., Giller, K.E. and Nyamangara J., Uptake of heavy metals by vegetables irrigated using wastewater and the subsequent risks in Harare, Zimbabwe. Physics and Chemistry of the Earth, 32, pp 1399-1405, 2007.

[17] Samuding, K., Ismail A., Mohd, T. and Abdul Rahman, M.H., Distribution of heavy metals profile in groundwater system at solid waste disposal site. European Journal of Scientific Research, 37, pp. 55-62, 2009.

[18] Duan, X.L., Wang, Z.S., Li, Q., Zhang, W.J., Huang, N., Wang, B.B. and Zhang, J.L., Health risk assessment of heavy metals in drinking water based on field measurement of exposure factors of Chinese people. Huan Jing KeXue, 32, pp. 1329-39, 2011.

[19] Mishra, S., Rakash, Dwivedi, S.P. and Singh, R.B. A review on epigenetic effect of heavy metal carcinogens on human health. The Open Nutraceuticals Journal, 3, pp. 188-193. 2010.

[20] American Public Health Association/American Water Works Association/Water Environment Federation (APHA/AWWA/WEF). Standard Methods for the Examination of Water and Wastewater, $20^{\text {th }}$ edition. American Public Health Association/American Water Works 
Association/Water Environment Federation, Washington, DC. United Book Press Inc: Maryland, 1998.

[21] Carter, J.T., Rice, E.W., Butchberger, S.G. and Lee, Y., Relationship between level of hetrotrophin bacteria and water quality. Water Research, 34, pp. 1495-1502, 2000.

[22] Moor, C., Lymberopoulou, T. and Volker J. Dietrich, V., Determination of heavy metals in soils, sediments and geological materials by ICP-AES and ICP-MS. Mikrochim. Acta, 136, pp. 123-128, 2001.

[23] Ministry of Regional Municipalities and Water Recourses (MEMWR). Sludge standards for land application (145/193, 1993). Ministry of Environment: Oman, 1993.

[24] Ministry of Regional Municipalities and Water Recourses (MEMWR). Standards for the minimization of pollution to air, water and soil. Ministry of Environment Decree No 52/1-Standards. Ministry of Environment: Oman, 1996.

[25] Adefemi, S.O. and Awokunmi, E.E., Determination of physico-chemical parameters and heavy metals in water samples from Itaogbolu area of Ondo-State, Nigeria. African Journal of Environmental Science and Technology, 4, pp. 145-148, 2010.

[26] Krasniqi, K., Krasniqi, I., Vasjari, M., Sefaja, L. and Zuka, A., The level of heavy metals in several alternative water sources in the area KastriotVushtrri-Drenas, in Kosovo. BALWOIS 2010- Ohrid: Republic of Macedonia, 2010.

[27] Lungu, M., Lazăr R. and Aldea, M.M., The quality of the sludge proceeded from groundwater treatment. Present Environment and Sustainable Development, NR. 4. National Research and Development Institute for Soil Science, Agrochemistry and Environment Protection: Bucharest. 2010.

[28] NSF International. Dietary supplement-Standard 173. Metal contaminant acceptance level. pp 1-22, 2003.

[29] The soil profile. New Jersey Agriculture Experiment Station., The soil profile: A newsletter providing information on issues relating to soils and plant nutrition in New Jersey. 16, pp. 2-4, 2012.

[30] Duruibe, J.O., Ogwuegbu, M.O. and Egwurugwu, J.N., Heavy metal pollution and human biotoxic effects. International Journal of Physical Sciences, 2, pp. 112-118, 2007.

[31] Iqbal, M.A., and Gupta, S.G., Studies on heavy metal ion pollution of ground water sources as an effect of municipal solid waste dumping. African Journal of Basic and Applied Sciences, 1, pp. 117-122, 2009.

[32] Salem, H.M., Eweida, E.A. and Farag, A. Heavy metals in drinking water and their environmental impact on human health. ICEHM. pp. 542- 556, 2000.

[33] Skeat, W.O. Manual of British water engineering practice. Vol. b: water quality and treatment. The institution of water engineers: London, 1969. 